\title{
Falling Real Wages During An Industrial Revolution
}

by

Antonio Ciccone*

October 1996

\begin{abstract}
The Industrial Revolution was characterized by technological progress and an increasing capital intensity. Why did real wages stagnate or fall in the beginning? I answer this question by modeling the Industrial Revolution as the introduction of a relatively more capital intensive production method in a standard neoclassical framework. I show that real wages fall in the beginning of an industrial revolution if and only if technological progress in the relatively more capital intensize sector is relatively fast.
\end{abstract}

JEL Classification: D5, N1, O1, O3.

* University of California at Berkeley and Universitat Pompeu Fabra. Many thanks to Mary Amity, Albert Carreras, and Albrecht Ritschl for comments on an earlier version. 


\section{Introduction}

Did real wages fall during the British Industrial Revolution? This question is part of the long standing, recently revived debate on workers' living standards during the British Industrial Revolution. The answer suggested by Peter Mathias (1983) and Peter Lindert (1994) is that real wages stagnated or fell in the beginning of the Industrial Revolution but increased rapidly in the later stages. ${ }^{1}$ The early empirical debate was accompanied by a heated theoretical discussion. Karl Marx, John Stuart Mill, David Ricardo, and Jean-Baptiste Say all discussed the effect of more capital intensive, industrial production methods on aggregate labor demand and real wages in their main works. ${ }^{2}$

From a modern perspective the theoretical foundations of this controversy seem difficult to understand. Economic historians agree that the Industrial Revolution was characterized by technological progress and a rising aggregate capital intensity, see Nicholas Crafts (1990), Phyllis Deane and W.A. Cole (1962), and Jonathan Feinstein (1978) for example. How could real wages have fallen at the same time? I answer this question by modeling the Industrial Revolution as the introduction of a relatively more capital intensive, "industrial" production method in a standard neoclassical framework. I show that aggregate labor demand and real wages fall temporarily if

\footnotetext{
${ }^{1}$ Friedrich Engels (1845), Karl Marx (1867), and George H. Wood (1899) were some of the early contributors to the empirical debate; for more recent results see Elizabeth W. Gilboy (1934), Peter Mathias (1983), Peter Lindert and Jeffrey Williamson (1983, 1985), Nicholas Crafts (1985), and John Brown (1990). The data in Lindert (1994) is based on Lindert and Williamson (1983). The empirical findings vary enormously with the time period, the region, the price-index and so on.

2 Marx in his Kapital, Mill in his Principles of Political Economy, Say in his Treatise on Political Economy, and Ricardo in the third edition of his Principles of Political Economy and Taxation. It seems that Marx thought that the introduction of industrial production methods would decrease labor demand, Mill and Say that they would increase labor demand, and Ricardo that they could decrease labor demand.
} 
and only if technological progress in the relatively more capital intensive sector is relatively fast. Falling real wages are accompanied by rising real returns to capital.

To see whether my model captures some of the basic characteristics of the Industrial Revolution, I take a detailed look at the cotton industry. I find that cotton production switched gradually to more capital intensive production methods. This may help explain why product wages in the cotton industry fell between 1806 and 1821 (and took until 1836 to recover the 1806 level) despite an increasing aggregate capital intensity and rapid technological progress.

The paper is structured as follows. The next section models the Industrial Revolution and contains my main results. Section 3 takes a detailed look at the cotton industry during the Industrial Revolution. Section 4 concludes. An appendix illustrates the theoretical argument with four simple pictures.

\section{The Model}

To see how the introduction of more capital intensive production methods affects real wages, I consider the simplest possible dynamic general equilibrium model. There will be three markets—a labor market, a capital market, and a final goods market -and two production methods for the final good—one more capital intensive than the other. I assume that all three market are perfectly competitive, that the supply of labor is perfectly inelastic and equal to $L$, and that the supply of savings $S$ is perfectly inelastic and equal to $S=s \mathcal{Y}$, where $\mathcal{Y}$ denotes aggregate income in the economy and $s$ the exogenous savings-rate. All endogenous variables will depend on time but I will suppress all time-subscripts.

The less capital intensive, "cottage" production method uses capital and labor. I assume that these factors enter with constant returns to scale and that returns to scale to capital are also constant and equal to $\alpha, 0<\alpha<1$, 


$$
\Upsilon_{\alpha}=\left(K_{\alpha}\right)^{\alpha}\left(A L_{\alpha}\right)^{1-\alpha}
$$

where $Y_{\alpha}$ denotes total production in the cottage sector, $L_{\alpha}$ and $K_{\alpha}$ the total amount of labor and capital employed in the cottage sector, and $A$ the level of (labor-augmenting) technology in the cottage sector.

It is commonly argued in the literature on the Industrial Revolution that industrial production methods used capital relatively more intensively, see Mark Blaug (1961), Deane and Cole (1962), and Phyllis Deane (1965) for example. To capture this I introduce a second production method,

$$
\Upsilon_{\beta}=\left(K_{\beta}\right)^{\beta}\left(B L_{\beta}\right)^{1-\beta} \text { with } 1>\beta>\alpha \text {, }
$$

where $Y_{\beta}$ denotes total production and $K_{\beta}$ and $L_{\beta}$ the total amount of capital and labor employed in this second, "industrial" production sector; $\beta>\alpha$ captures that the industrial production method uses capital more intensively than the cottage production method at the same factor prices; and $B \neq A$ captures that the level and growth rate of (labor-augmenting) technology may differ between the cottage production sector and the industrial production sector

To close the model in a simple way, I assume that capital depreciates at some exogenous rate $\delta>0$ in both sectors and that capital and labor are perfectly mobile between the cottage and the industrial production sector. Extending the model for imperfect factor mobility between the two sectors, for differences in depreciation rates, for positive gross investment constraints, or for a minimum scale in the more capital intensive sector would be straightforward and leave the model's conclusions unchanged. 
The aggregate technology in the cottage and the industrial production sector in (1) and (2) make it clear that a downward shift in labor demand and a falling real wage can only be explained as a general equilibrium effect of either a rising aggregate capital intensity or a sectoral difference in the rate of technological change. In partial equilibrium, an increase in the level of technology and the amount of capital used in production can only increase labor demand: Denoting the real wage with $w$, profit-maximization in-say-the industrial production sector implies that

$$
w=(1-\beta) B^{1-\beta}\left(K_{\beta} / L_{\beta}\right)^{\beta}
$$

An increase in the amount of capital or the level of technology shift the labor demand curve upwards.

Before discussing why aggregate labor demand and real wages may fall despite an increasing aggregate capital intensity and technological progress in both sectors, I consider two equilibria where real wages rise as expected: The cottage production equitibrium - where all production uses the cottage production method and the industrial production equilibrium —where all production uses the industrial production method.

\section{Cottage Production and Industrial Production Equilibrium}

In the cottage production equilibrium, all available resources are used in cottage production. The capital intensity in the cottage production sector must therefore be equal to the aggregate capital intensity $k \equiv K / L$. This implies that real wages in the economy and the cottage production sector will be equal to $(1-\alpha) A^{1-\alpha}(K / L)^{\alpha}$ and increase with the aggregate capital intensity and improvements in technology. Assuming that the economy starts below its neoclassical cottage production steady- 
state, the aggregate capital intensity per efficiency worker $K / A L$ would also increase. ${ }^{3}$ This would result in falling real returns to capital $r$,

$$
r=\alpha \Upsilon / K=\alpha(K / A L)^{-(1-\alpha)}
$$

Rearranging (5) to get that $r K / \Upsilon=\alpha$ demonstrates that improvements in technology and an increasing aggregate capital intensity would leave the distribution of income between capital and labor unchanged in the cottage production equilibrium.

Real wages and real returns to capital in the industrial production equilibrium evolve in the same way as in the cottage production equilibrium: Real wages increase and real returns to capital fall for the same reasons as in the cottage production equilibrium. The main difference between the cottage production equilibrium and the industrial production equilibrium is that the share of capital in income $r K / \gamma=\beta$ is higher and the share of labor in income $w L / Y=1-\beta$ lower in the industrial production equilibrium. This is because the industrial production sector uses capital more intensively at the same factor prices.

Summing up: Real wages increase and real returns to capital fall when all resources are employed in either the cottage production sector or the industrial production sector. It remains to be seen whether the allocation of all resources to one sector only may be an equilibrium in this simple neoclassical model. More importantly, it remains to be seen whether there are equilibria where both production methods exist side by side. These two questions are linked and will be discussed in the next section.

${ }^{3}$ Assuming that the economy starts below its neoclassical cottage production steady-state amounts to assuming that the initial amount of capital $K_{0}$ is low relative to the initial labor 


\section{Industrial Transition}

For cottage and industrial production methods to exist side by side, they must pay the same rate of return to capital and the same wage. Combined with profitmaximization in the two sectors, this implies that the marginal product of capital and labor must be identical in the two sectors. Formally,

$$
r=\alpha\left(k_{\alpha} / A\right)^{-(1-\alpha)}=\beta\left(k_{\beta} / B\right)^{-(1-\beta)}
$$

and

$$
w=(1-\alpha) A\left(k_{\alpha} / A\right)^{\alpha}=(1-\beta) B\left(k_{\beta} / B\right)^{\beta},
$$

where $k_{\alpha}$ denotes the capital intensity in the cottage production sector and $k_{\beta}$ the capital intensity in the industrial production sector.

Equations (6) and (7) can be combined to show that the industrial production method uses capital more intensively in the industrial transition. Dividing (6) by (7) and denoting equilibrium values with asterisks, it follows that

$$
k_{\beta}^{*}=\gamma k_{\alpha}^{*}
$$

where $\gamma=(\beta /(1-\beta)) /(\alpha /(1-\alpha))>1$ because I assume $\beta>\alpha$.

A somewhat more interesting conclusion emerges by substituting (8) in (6) to get the equilibrium capital intensity in the cottage production sector during the industrial transition,

$$
k_{\alpha}^{*}=A(A / B)^{\theta} \mu
$$

force in efficiency units $A_{0} L$ so that $\hat{k}_{0}=s\left(K_{0} / A_{0} L\right)^{-(1-\alpha)}-\delta>a$. In the steady-state, the real return to capital would be constant but real wages would still increase if $a>0$. 
where $\mu$ is some unimportant constant and $\theta=(1-\beta) /(\beta-\alpha)>0 ;(9)$ yields my first claim about the industrial transition:

Proposition 1: Real retums to capital rise during the industrial transition if and only if technological change is faster in the relatively more capital intensive sector.

This is because faster technological change in the industrial sector, $b>a$, and (9) imply that the amount of capital per efficiency worker in the cottage production sector, $k_{\alpha}^{*} / A$, falls during the industrial transition; (6) shows that this implies increasing real returns to capital in the cottage sector and the economy.

My main interest is the evolution of real wages during the industrial transition. Equilibrium real wages during the industrial transition can be calculated by substituting (9) into (7) to get

$$
w=(1-\alpha) A(A / B)^{\alpha \theta} \mu^{\alpha}
$$

(10) establishes the main claim in the paper:

Proposition 2: Real wages fall during the industrial transition despite an increase in the aggregate capital intensity and total factor productivity growth in all sectors if and only if technological change in the industrial production sector is fast relative to technological change in the cottage production sector.

The precise condition on the relative rate of technological change in the two sectors is that

$$
\alpha(1-\beta) b>\beta(1-\alpha) a
$$


it is straightforward to show that the aggregate capital intensity increases during the industrial transition.

During the industrial transition capital and labor are re-allocated to the industrial production sector. The capital intensity falls in both the cottage production sector and the industrial production sector-even though the aggregate capital intensity will be rising. If technological progress is fast in the industrial production sector or slow in the cottage production sector, the falling capital intensity in the two sectors decreases aggregate labor demand and equilibrium real wages, see Figure 1 . The appendix illustrates the theoretical argument for the case $a=0$ with four simple pictures.

\section{Figure 1: Decreasing Labor Demand During An Industrial Revolution}

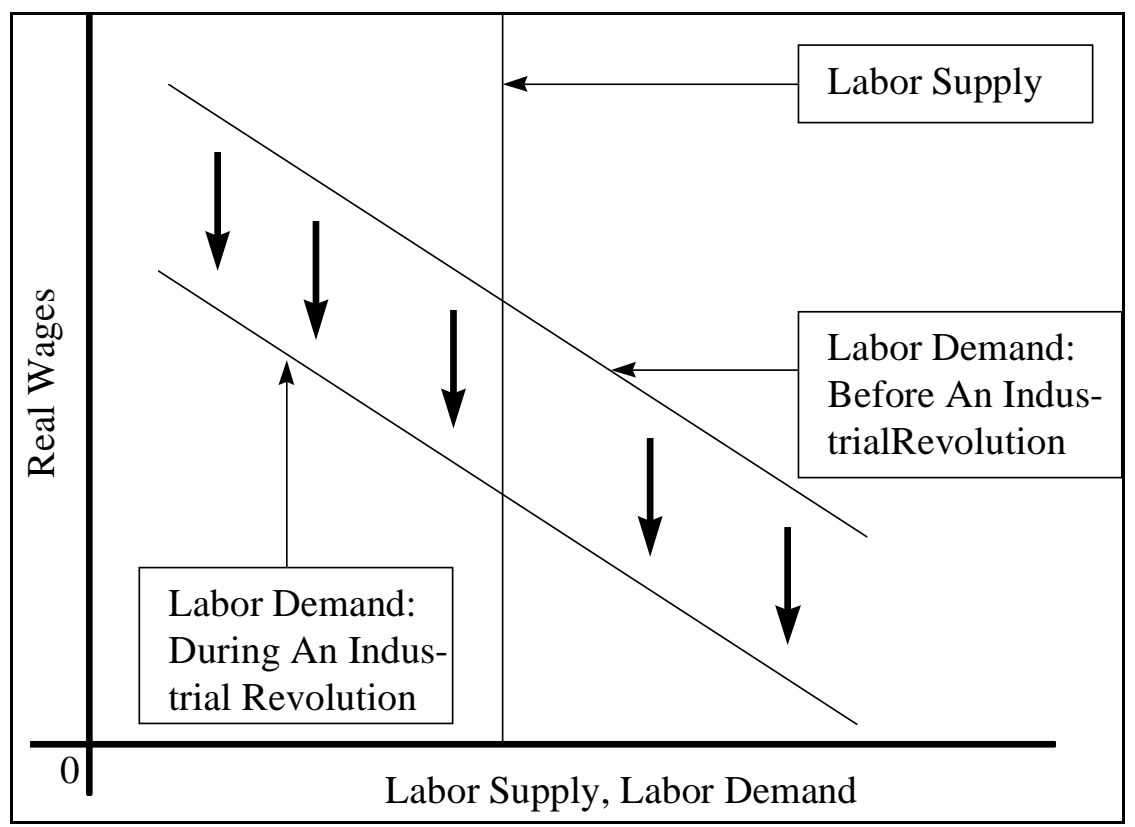


Notes to Figure 1: Aggregate labor demand during an industrial revolution when total factor productivity in the more capital intensive sector is relatively fast (the exact condition is in (11)).

Two simple questions remain to be resolved: Why would the economy ever use the cottage production method if the industrial production method is available? and, When does the real wage hit bottom?

Both questions can be answered by taking a more detailed look at factor markets during the industrial transition. Let $l_{\alpha}, 0 \leq l_{\alpha} \leq 1$, be the share of the labor force employed in the cottage production sector and $l_{\beta}, 0 \leq l_{\beta} \leq 1$, the share of the labor force employed in the industrial production sector. Labor and capital market clearing during the industrial transition imply that

$$
l_{\alpha} k_{\alpha}^{*}+\left(1-l_{\alpha}\right) k_{\beta}^{*}=k
$$

As the industrial production sector uses capital more intensively than the cottage production sector in the industrial transition, $k_{\alpha}^{*}<k_{\beta}^{*}$, (12) yields

$$
k_{\alpha}^{*}<k<k_{\beta}^{*}
$$

during the industrial transition. It is straightforward to show that this condition is not only necessary but also sufficient for the cottage and industrial production method to exist side by side in equilibrium. ${ }^{4}$

\footnotetext{
4 A simple way to see this is the following. The competitive equilibrium must be Paretoefficient. It is straightforward to see (from figure A3 in the appendix, for example) that allocating all capital and labor into one sector only does not maximize aggregate production when (13) is satisfied.
} 
The economy will use all resources in the cottage sector-even though the industrial production method is available—when the aggregate capital intensity is lower than $k_{\alpha}^{*}$, that is

$$
k \leq k_{\alpha}^{*} \equiv A(A / B)^{\theta} \mu
$$

where $\mu$ is some unimportant constant and $\theta=(1-\beta) /(\beta-\alpha)>0$. This is because the relatively more capital intensive and technologically underdeveloped industrial production method cannot compete with the cottage production method as capital is relatively scarce and therefore relatively expensive.

The factors that start the industrial transition and lead to the first introduction of more capital intensive, industrial production methods are readily seen from (14): Industrial production methods may become competitive with cottage production methods because of an increase in the supply of capital or relatively fast technological change in the industrial production sector (the precise condition is $(1-\beta) b>(1-\alpha) a$ and is always satisfied if the condition for real wages to fall during the industrial transition in (11) is satisfied).

During the industrial transition, the functional income distribution and the sectoral allocation of labor change smoothly. The share of labor in the industrial production sector is

$$
l_{\beta}^{*}=\frac{k-k_{\alpha}^{*}}{k_{\beta}^{*}-k_{\alpha}^{*}}
$$

and increases gradually with the aggregate capital intensity and technological improvements in the industrial production sector. The share of capital in income is

$$
\frac{r K}{\Upsilon}=\frac{\alpha(1-\beta)+(\beta-\alpha) l_{\beta}^{*}}{(1-\beta)+(\beta-\alpha) l_{\beta}^{*}}
$$


and increases gradually from $\alpha$ to $\beta$ as labor shifts from the cottage production sector to the industrial production sector.

Real wages hit bottom when the industrial transition comes to an end because the cottage production sector can no longer compete with the industrial production sector. This will happen when the aggregate supply of capital or the relative level of technology in the industrial production sector have risen sufficiently to satisfy

$$
k \geq k_{\beta}^{*} \equiv \gamma A(A / B)^{\theta} \mu
$$

Once (15) holds, real wages begin to rise again and real rates of return to capital begin to fall. Figure 2 illustrates the predicted time-path for real wages before, during, and after the industrial transition when the condition in (11) is satisfied.

\section{Figure 2: Real Wage, Real Return to Capital, and the Aggregate Capital Intensity. Before, During, and After an Industrial Revolution.}

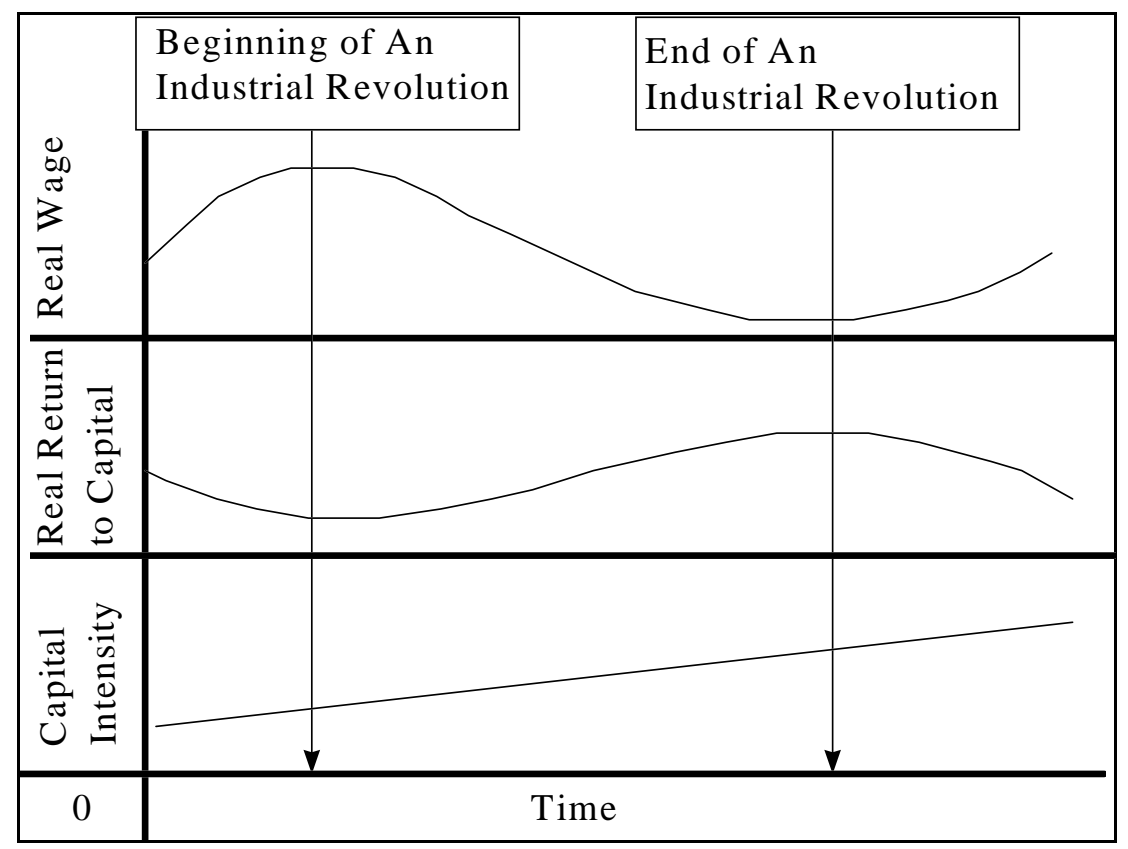


Notes to Figure 2: Time-path for real wages, real returns to capital, and aggregate capital intensity predicted by the dynamic neoclassical model with two methods of production for final goods, increasing total factor productivity in all sectors, and relatively fast total factor productivity growth in the more capital intensive sector (the exact condition is in (11)).

The predicted time-path for the real rate of return to capital is the exact opposite of the predicted time-path for real wages: The real return to capital falls when real wages increase and increases when real wages fall. The increase in real returns to capital and the fall in real wages is accompanied by an increasing aggregate capital intensity.

\section{Falling Product Wages in the Cotton Industry During the Industrial Revolution ${ }^{5}$}

To see whether the model in the previous section captures some of the basic characteristics of the Industrial Revolution, I now take a detailed look at the cotton industry.

Cotton production grew very rapidly during the British Industrial Revolution: The average annual growth rate was above 7 percent between 1770 and 1831, which took cotton from less than 3 percent of value added in 1770 to more than 22 percent in 1831, see Nicholas Crafts (1990). This is one reason why cotton is regarded as a key industry of the Industrial Revolution, with some economists-Joseph Schumpeter (1939) for example—arguing that the British Industrial Revolution can be almost reduced to the history of the cotton industry. The other reason is that cotton was one of the most thoroughly transformed industries during the Industrial Revolution. Cotton production experienced many 
technological breakthroughs starting before the Industrial Revolution with Kay's flying shuttle and Paul's carding machine and continuing during the Industrial Revolution with Arkwright's water frame, Crompton's mule, the introduction of the Boulton and Watt steam-engine, and the use of power-looms in 1820s, 1830s, and 1840s. Inbetween these major technological breakthroughs there where many relatively small, complementary improvements. Total factor productivity in the cotton industry grew very rapidly as a result: Estimates of average annual total factor productivity growth between 1780 and 1860 range from 1.8 to 2.6 percent, see Donald McCloskey (1981) and Crafts (1990).

It is commonly argued that rapid technological change and more capital intensive production methods went together during the Industrial Revolution. Cotton was among the first industries to abandon labor-intensive cottage production methods and adopt labor-saving, power-driven machinery on a large scale. In their respective studies of the cotton industry, Blaug (1961) finds that each factory worker operated two power-looms while a cottage worker operated one hand-loom; ${ }^{6}$ S.D. Chapman (1972) regards the higher capital intensity required for efficiency with industrial production methods as the main reason for the increase in firm size; and Deane (1965) argues that an increasing proportion of the income generated in the cotton industry went to entrepreneurs. Deane and Cole (1962) present data on wage income and value added in the cotton industry from 1819 onwards; their results indicate a falling labor share between 1819 and 1849 and a stable labor share after 1850 , see Table1.

5 I follow Phyllis Dean's (1965) description of the cotton industry.

${ }^{6}$ John Butt and S.D. Chapman (1988) estimate the cost of a power-loom to be 17 British pounds and the cost of a hand-loom to be 10 British pounds in 1811-1812. 
Table 1: Labor Share in the British Cotton Industry 1819-1946

\begin{tabular}{|c|c|}
\hline Years & Labor Share \\
\hline $\mathbf{1 8 1 9 - 1 8 2 1}$ & 44 percent \\
\hline $\mathbf{1 8 2 4 - 1 8 2 6}$ & 43 percent \\
\hline $\mathbf{1 8 2 9 - 1 8 3 1}$ & 42 percent \\
\hline $\mathbf{1 8 3 4 - 1 8 3 6}$ & 35 percent \\
\hline $\mathbf{1 8 3 9 - 1 8 4 1}$ & 32 percent \\
\hline $\mathbf{1 8 4 4 - 1 8 4 6}$ & 30 percent \\
\hline
\end{tabular}

Notes to Table 1: Table calculated from figures on total wages and value added in Phyllis Deane and W.A. Cole (1962).

Despite rapid improvements in industrial production methods, the shift to the factory system was rather continuous. Before the Industrial Revolution, many British families had engaged in some kind of textile manufacturing in extensions to their cottages. The new factory system did not immediately displace this cottage industry. Industrial production and cottage production existed side by side and supplemented each other for a large period of time, between 1780 and 1850 or so. Some estimates indicate that the number of cottage workers exceeded the number of factory workers until the 1830s, see Chapman (1972). This is because different parts of the cotton production process were integrated into the factory system at different points in time. Carding and spinning, for example, became a factory process in the 1780 s, some 40 years before weaving.

Current and past historical research has concentrated on consumption wages as one of the indicators of workers' living standards during the Industrial Revolution, see for example Lindert and Williamson (1983), Crafts (1985), and Brown (1990). This is probably the reason why there is no published product wage time series for the cotton industry during the Industrial Revolution. Fortunately, time series on money wages in the cotton textile industry and cotton textile prices are readily available as both are crucial for the calculation of consumption wages. Figure 3 calculates the cotton textile product wage using the cotton textile money wage for all 
male and female manual workers in Britain since 1806 published by Charles Feinstein (1995b), the Rufus Tucker (1936) textile price index between 1806 and 1815, and the Lars Sandberg (1968) cotton textile price index between 1815 and 1849. ${ }^{7}$ A clear U-shaped pattern emerges with cotton product wages falling between 1806 and 1821 and rising thereafter. ${ }^{8}$

\section{Figure 3: Product Wages is the British Cotton Industry}

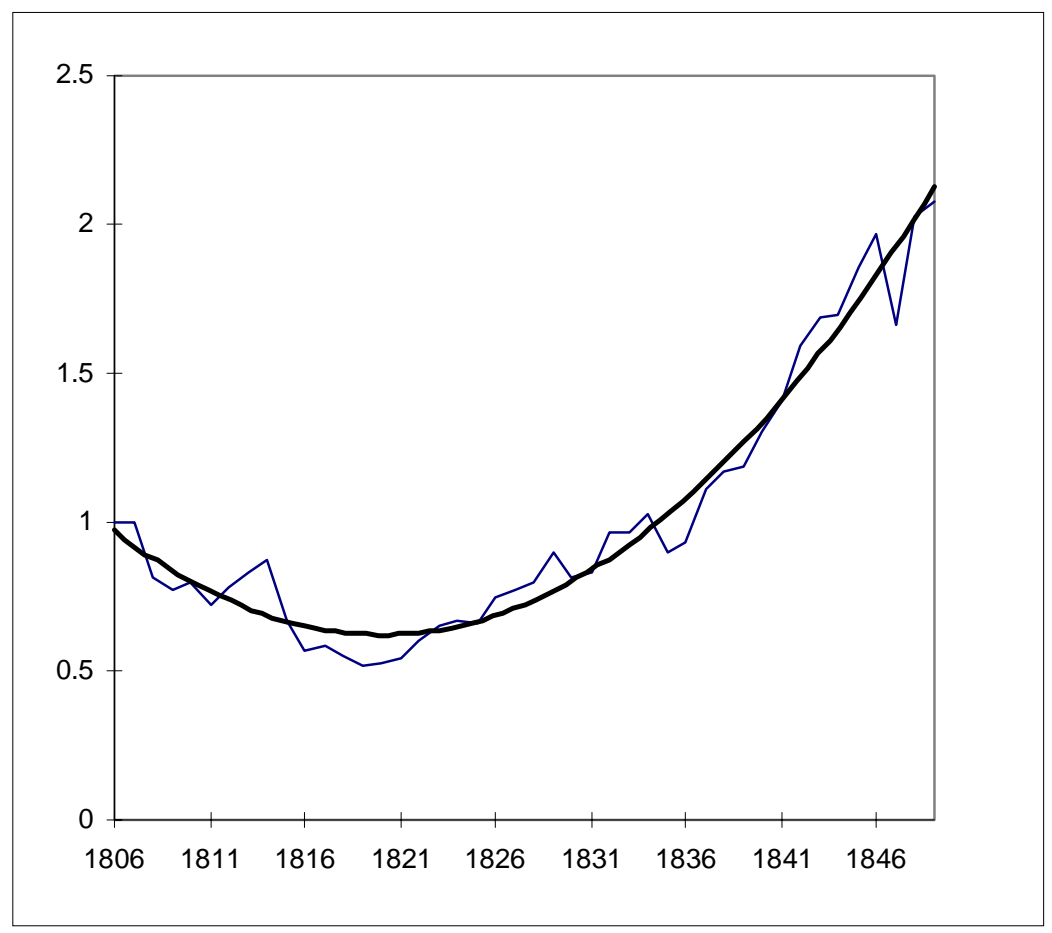

7 These are the most commonly used cotton textile price indices. See Lindert and Williamson (1983) and (1985) for example. The Sandberg index—which starts in 1815-is generally regarded to be superior to the Tucker index.

8 To calculate the product wage in the cotton industry before 1806 is difficult because there is no nominal wage series for cotton workers. Using the nominal wage series for all manual workers in Feinstein (1995b) instead would yields a rising product wage between 1780 and 1806. 
Notes to Figure 3: Product wages in the British cotton industry between 1806 and 1850 (jagged line, I have set product wages in 1806 to unity) and fitted polynomial. Nominal wages for cotton textile workers from 1806 to 1850 from Feinstein (1995b). Cotton textile prices for 1806-1815 from Tucker (1936) and for 1815-1850 from Sandberg (1968).

The fall in product wages between 1806 and 1821 would make it desirable to have data on total factor productivity growth and the increase in capital intensity for the cotton industry in this specific period. Unfortunately, such data does not exist. We only know that average annual total factor productivity growth between 1780 and 1860 was above 1.8 percent and that the capital intensity in the Lancashire cotton industry-where much of English cotton production was concentrated—doubled between 1834 and 1856, see Blaug (1961). If we apply the economy-wide experience during the Industrial Revolution to the cotton industry, then total factor productivity growth was faster in 1800-1830 than before and thereafter, and the capital intensity was increasing, see Crafts (1990) and Charles Feinstein (1978). What we know about this specific period is that the integration of weaving into the factory system began 1810 or so, with the adoption of the powerloom. ${ }^{9}$ Hand-loom weavers operating in cottage extensions started to loose their independence, as spinners had done 40 years before them. We also know that power-loom weaving was more than three times more capital intensive than handloom weaving: Power-loom weavers operated two power-looms, valued at 17 British pounds in 1811-1812, while hand-loom weavers operated only one hand-loom, valued at 10 British pounds in 1811-1812, see Blaug (1961) and John Butt and S.D. Chapman (1988).

${ }^{9}$ An early version of the power-loom had been invented in the 1780 s but early attempts of integrating it into the factory system failed, see Deane (1965). 
Given the lack of data for the cotton industry in this specific period, it may be useful to review some observations by students of this apparently important period in the history of the cotton industry. Blaug (1961) agrees with Deane (1965) that one interesting fact about this specific period is that "although prices fell steeply, profits were well maintained." Deane argues that the cheap labor supply from hand-loom weavers who were driven out of business by the factory competition was probably the most important reason for the cotton industry's ability to maintain profits.

Overall, the history of the cotton industry during the Industrial Revolution lends support to the model in section 2. The cotton industry switched to more capital intensive production methods. Industrial and cottage production methods existed side by side, at least in the weaving of cotton where it took 40 years or so for the industrial power-loom to eliminate hand-weaving by cottage workers. The fall in product wages started around the time the cottage industry in weaving began to shrink. This may explain why product wages fell temporarily despite rapid total factor productivity growth and an increasing capital intensity. ${ }^{10}$

${ }^{10}$ An alternative explanation for falling product wages in the cotton industry is skilled-labor substituting technological progress. The argument appears to be that the power-loom enabled factory-owners to hire low paid children and women to do the job of better paid men. Unfortunately, there is no data about the relative employment of children and women and men over the period 1806 to 1850 ; but there is data for the period 1834 to 1850 for Lancashire in Blaug (1961). Taking into account that weaving was still being integrated into factories in this period and that most of the English cotton production was concentrated in Lancashire, this data may be good enough for a rough check.

Percentages of Children, Women, and Men in the Lancashire Cotton Industry

\begin{tabular}{|l|l|l|l|l|}
\hline & $\mathbf{1 8 3 4}$ & $\mathbf{1 8 3 9}$ & $\mathbf{1 8 4 7}$ & $\mathbf{1 8 5 0}$ \\
\hline Children under 13 & 13.3 & 4.7 & 5.8 & 4.6 \\
\hline Males 13 to 18 & 12.5 & 16.6 & 11.8 & 11.2 \\
\hline Females over 13 & 47.5 & 53.8 & 55.3 & 55.5 \\
\hline Males over 18 & 26.4 & 24.9 & 24.9 & 28.7 \\
\hline
\end{tabular}

The only marked tendency in the table is for children to be substituted by women. 


\section{Conclusions}

The effect of more capital intensive, industrial production methods on labor demand and real wages became an important theoretical and empirical issue during the British Industrial Revolution. Mill (1848), for example, argued that "the labouring classes as a collective body cannot suffer temporarily by the introduction of machinery." Although he thought that some workers may be worse off in the short run, because they would be displaced or because their specific skills might loose value. Ricardo thought otherwise. He gives an example where the introduction of machinery raises average labor productivity but decreases wages of all workers, see Ricardo (1821) for the original argument and Samuelson (1988) for a mathematical vindication.

This paper presents a very simple neoclassical equilibrium model to analyze the exact same question: How does the introduction of industrial production methods affect real wages? The answer is surprising and surprisingly simple: The introduction of productions methods that are more capital intensive at the same factor prices will shift the aggregate labor demand curve dowen and decrease equilibrium real wages temporarily if and only if technological change in the relatively more capital intensize sector is relatively fast. The reason is that rapid technological change in the more capital intensive sector leads to a shift of labor and capital from the less to the more capital intensive sector. The shift of labor relative to capital is rapid enough to decrease the capital intensity in the more capital intensive sector but not sufficiently rapid to increase the capital intensity in the less capital intensive sector. The capital intensity in both sectors falls as a result-even though the aggregate capital intensity will be rising. This simple general equilibrium explanation for stagnating or falling real 
wages seems to capture some of the most basic characteristics of the Industrial Revolution.

\section{Appendix}

This appendix illustrates the main argument when there is no technological progress in the less capital intensive sector, $a=0$.

Figure A1: Cottage Production Equilibrium

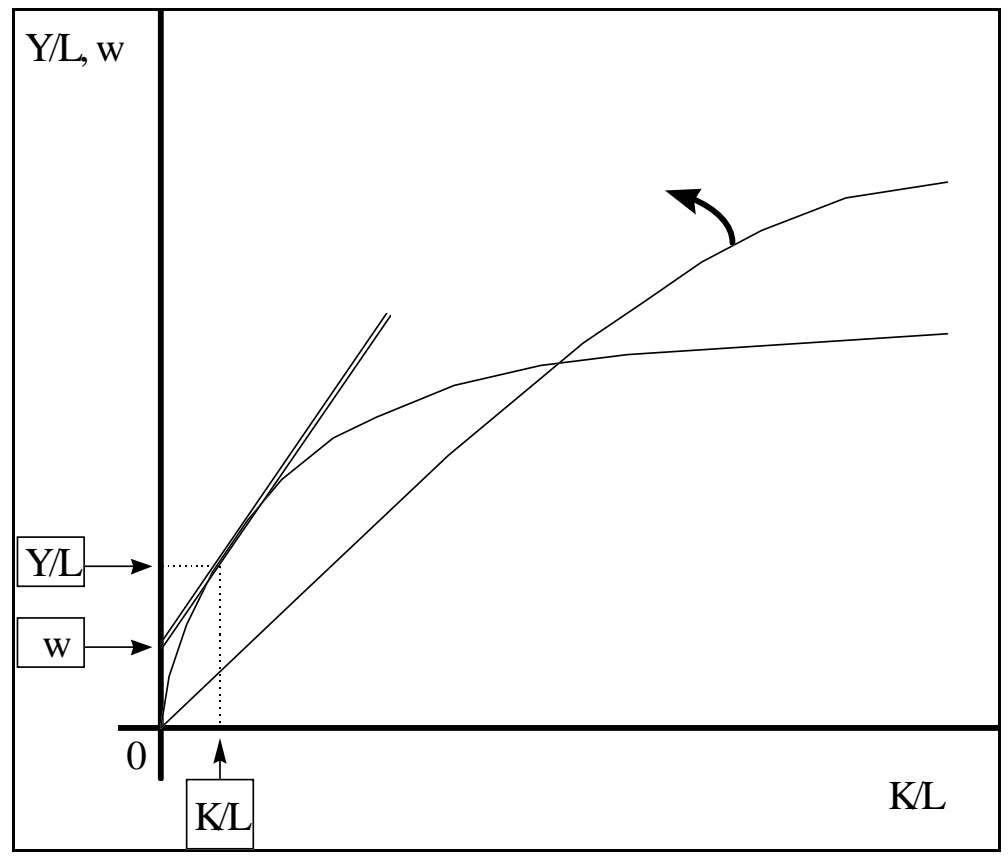

Notes: The aggregate capital intensity is on the x-axis. The y-axis gives both the average labor productivity and the real wages in the economy. The slope of the tangent is the real return of capital. The intersection point of the tangent and the $y$-axis is the real wage. The arrow indicates that the production function in the more capital intensive sector shifts up because of technological progress $(b>0)$. The production function in the less capital intensive sector remains unchanged $(a=0)$. 
Figure A2: Beginning of An Industrial Revolution

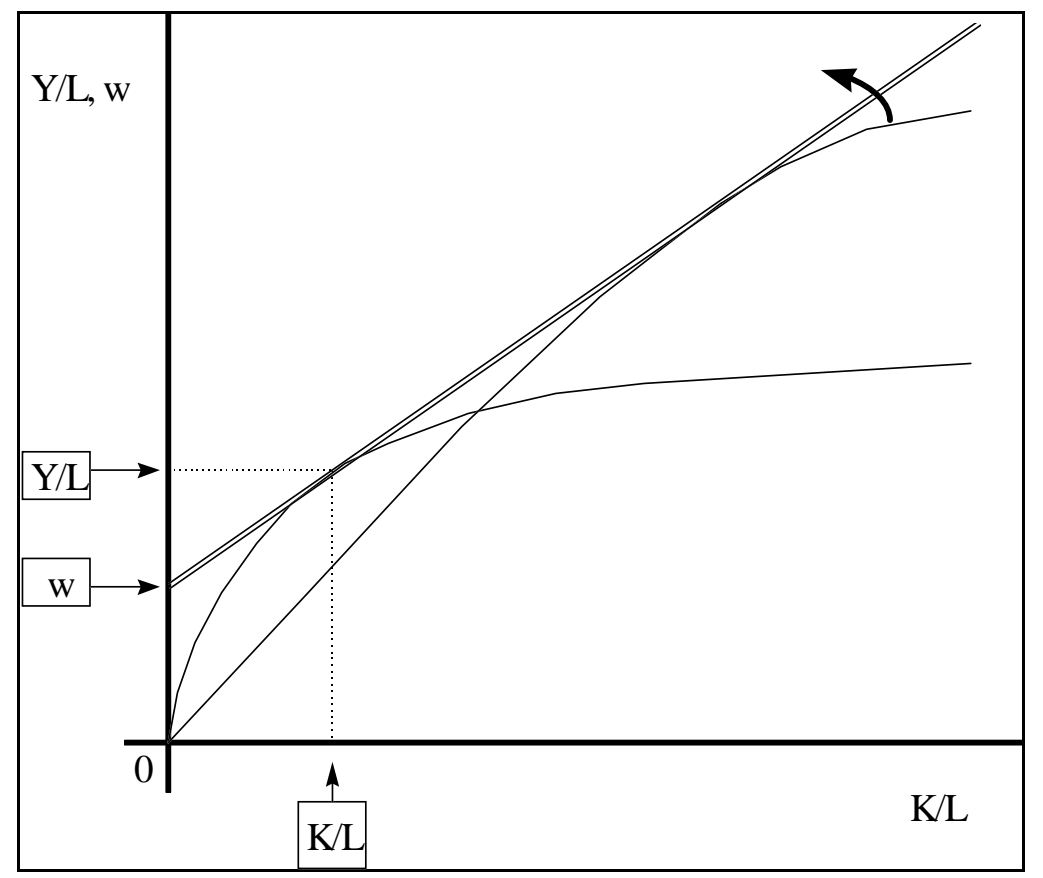

Notes: The beginning of an industrial revolution. The real return to capital (the slope of the tangent) and the real wage (the intersection point of the tangent and the y-axis) are the same in both sectors. The arrow indicates that the production function in the more capital intensive sector is still shifting up because of technological progress $(b>0)$. The production function in the less capital intensive sector continues to remain unchanged $(a=0)$. 
Figure A3: Falling Real Wages During An Industrial Revolution

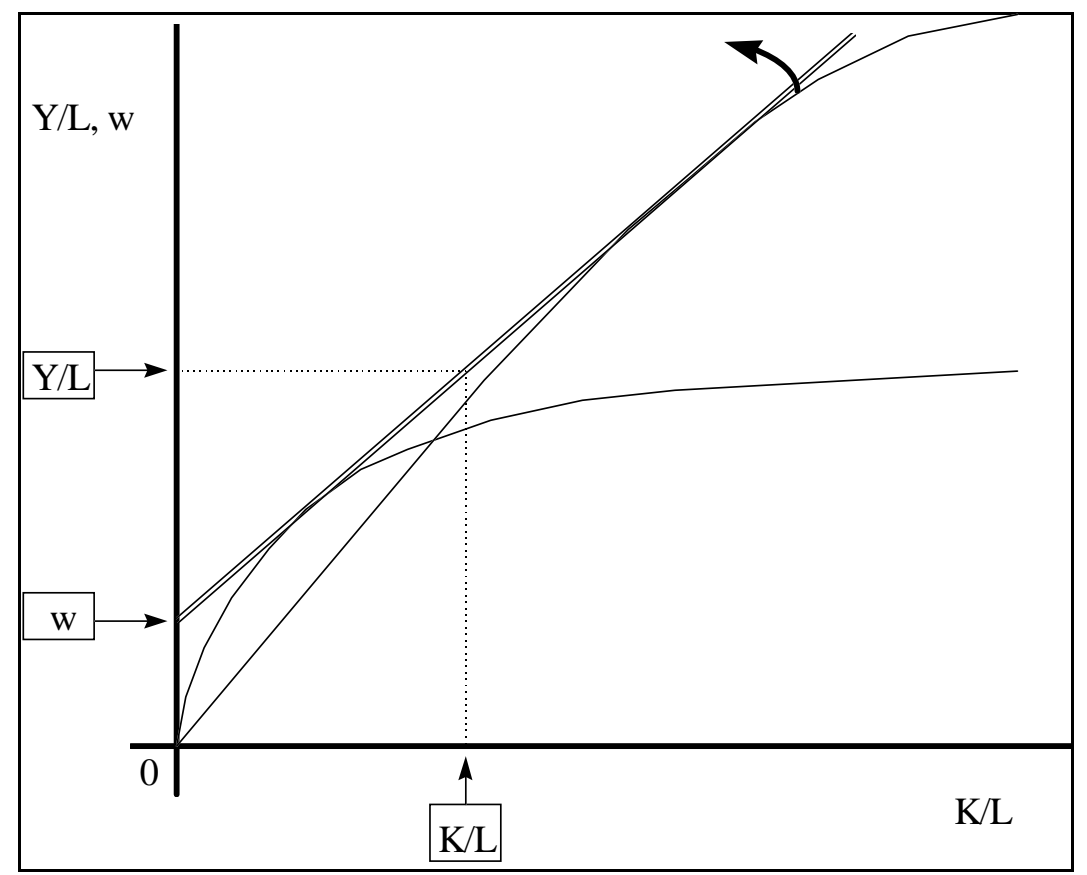

Notes: During the industrial revolution the production function in the more capital intensive sector is still shifting up because of technological progress $(b>0)$. Both sectors are existing side by side which implies that the tangent must just touch the production functions of the less capital intensive sector and the more capital intensive sector. Technological progress in the more capital intensive sector rotates the tangent anti-clockwise because the production function in the less capital intensive sector continues to remain unchanged $(a=0)$. This implies that the intersection point of the tangent and the y-axis shifts down and the real wage decreases during an industrial revolution. 
Figure A4: The Industrial Production Equilibrium

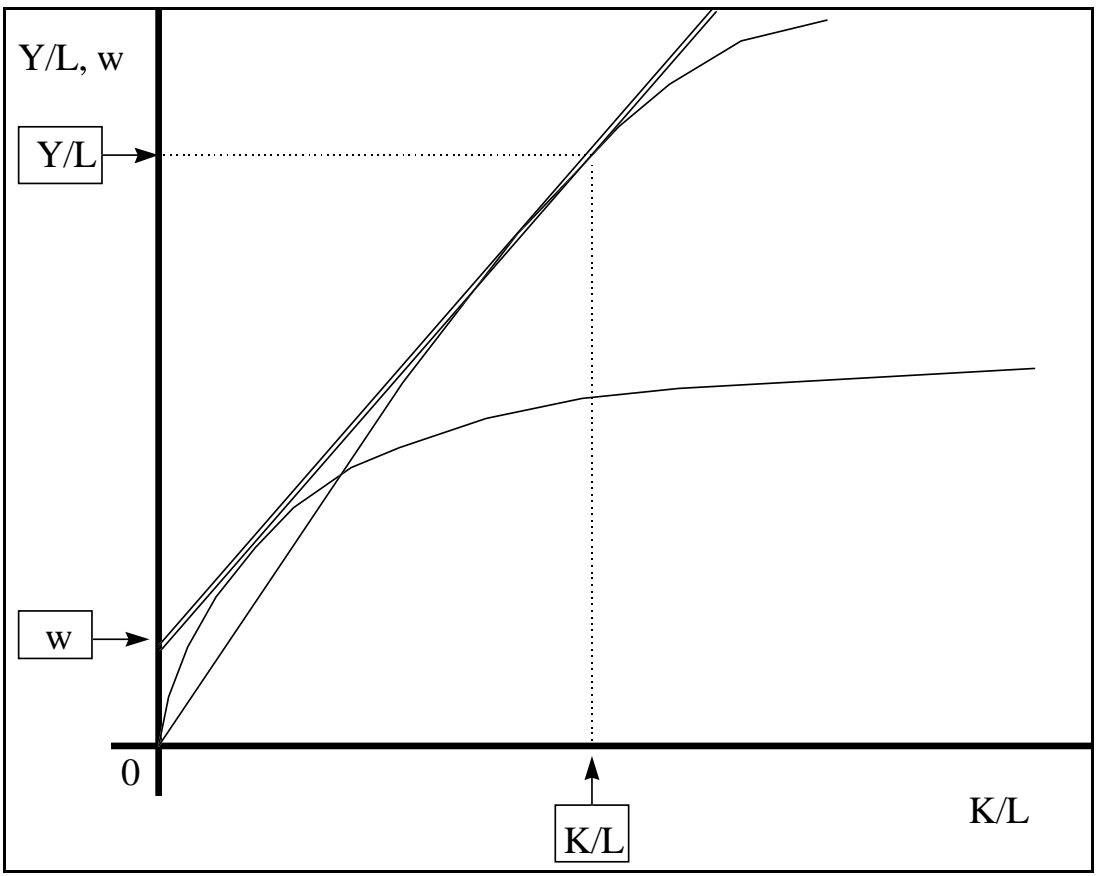

Notes: The steadily improving technology in the more capital intensive sector and the increase in the aggregate capital intensity make it impossible for firms in the less capital intensive sector to compete against firms in the more capital intensive sector. All resources are therefore employed in the more capital intensive sector. 


\section{References}

Blaug, Mark (1961), "The Productivity of Capital in the Lancashire Cotton Industry During the Nineteenth Century," Economic History Reviewe, 13, pp. 358-381.

Brown, John C. (1990), "The Condition of England and the Standard of Living: Cotton Textiles in the Northwest, 1806-1850," Gournal of Economic History, 50, pp. 591-615.

Chapman, S.D. (1972), The Cotton Industry in the Industrial Revolution, London, Macmillan.

Butt, John and Chapman, S.D. (1988), "The Cotton Industry," pp. 105-125 in Charles H. Feinstein and Sidney (eds) Studies in Capital Formation in the United Kingdom, Oxford, Oxford University Press.

Crafts, Nicholas F.R. (1985), "English Worker' Real Wages During the Industrial Revolution: Some Remaining Problems," Fournal of Economic History 45, pp. 139144.

Crafts, Nicholas F.R. (1990), British Economic Growth During the Industrial Revolution, Oxford, Clarendon Press.

Deane, Phyllis and W.A. Cole (1962), British Economic Growth, Cambridge (England), Cambridge University Press.

Deane, Phyllis (1965), The First Industrial Revolution, Cambridge (England), Cambridge University Press.

Engels, Friedrich (1845), Die Lage der Arbeitenden Klasse In England, Leipzig, Otto Wigand Verlag.

Feinstein, Charles H. (1978), "Capital Formation in Great Britain," pp. 28-96 in P. Mathias and M.M. Postan (eds.), Cambridge Economic History of Europe, Cambridge (England), Cambridge University Press.

Feinstein, Charles H. (1995a), "Changes in Nominal Wages, the Cost of Living, and Real Wages in the United Kingdom over Two Centuries, 1780-1990," pp. 258266 in Peter Scholliers and Vera Zamagni (eds.), Labour's Reweard, Hants, Edward Elgar.

Feinstein, Charles H. (1995b), "Appendix: Nominal Wages and Costs of Living Series, 19th and 20th centuries, United Kingdom, 1780-1990," pp. 258-266 in Peter Scholliers and Vera Zamagni (eds.), Labour's Reweard, Hants, Edward Elgar.

Gilboy, Elizabeth W. (1934), "The Cost of Living and Real Wages in the Eighteenth Century," Review of Economic Statistics. 
Lindert, Peter H. and Jeffrey G. Williamson (1983), "English Workers' Living Standards During the Industrial Revolution: A New Look," Economic History Review 36, pp. 1-25.

Lindert, Peter H. and Jeffrey G. Williamson (1985), “English Workers' Real Wages: A Reply to Crafts," Joumal of Economic History 45, pp. 145-153.

Lindert, Peter H. (1994), "Unequal Living Standards," in Roderick C. Floud and Donald N. McCloskey (eds.), The Economic History of Britain Since 1700, Cambridge (England), Cambridge University Press.

Marx, Karl (1867) Das Kapital, Hamburg, Otto Meisner Verlag.

Mathias, Peter (1983) The First Industrial Nation, Methuen. London and New York.

McCloskey, Donald N. (1981), “The Industrial Revolution: A Survey," pp. 242271 in Roderick C. Floud and Donald N. McCloskey (eds.), The Economic History of Britain Since 1700, Cambridge (England), Cambridge University Press.

Mill, John Stuart (1848), Principles of Political Economy, London.

Ricardo, David (1821), Principles of Political Economy and Taxation, Third Edition, London, Murray.

Samuelson, Paul (1988), "Mathematical Vindication of Ricardo on Machinery," Fournal of Political Economy, 96, pp. 274-286.

Sandberg, Lars (1968) "Movements in the Quality of British Cotton Textile Exports, 1815-1920" Foumal of Economic History, 28, pp. 1-26.

Say, Jean-Baptiste (1880), A Treatise on Political Economy, Philadelphia, Claxton, Remsen and Haffelfinger.

Schumpeter, Joseph (1939) Business Cycles, New York, McGraw-Hill.

Tucker, Rufus (1936) "Real Wages of Artisans in London, 1729-1935," Fournal of the American Statistical Association, 31, pp. 73-84.

Wood, George H. (1899), "The Course of Average Wages Between 1790 and 1860," Economic Foumal. 